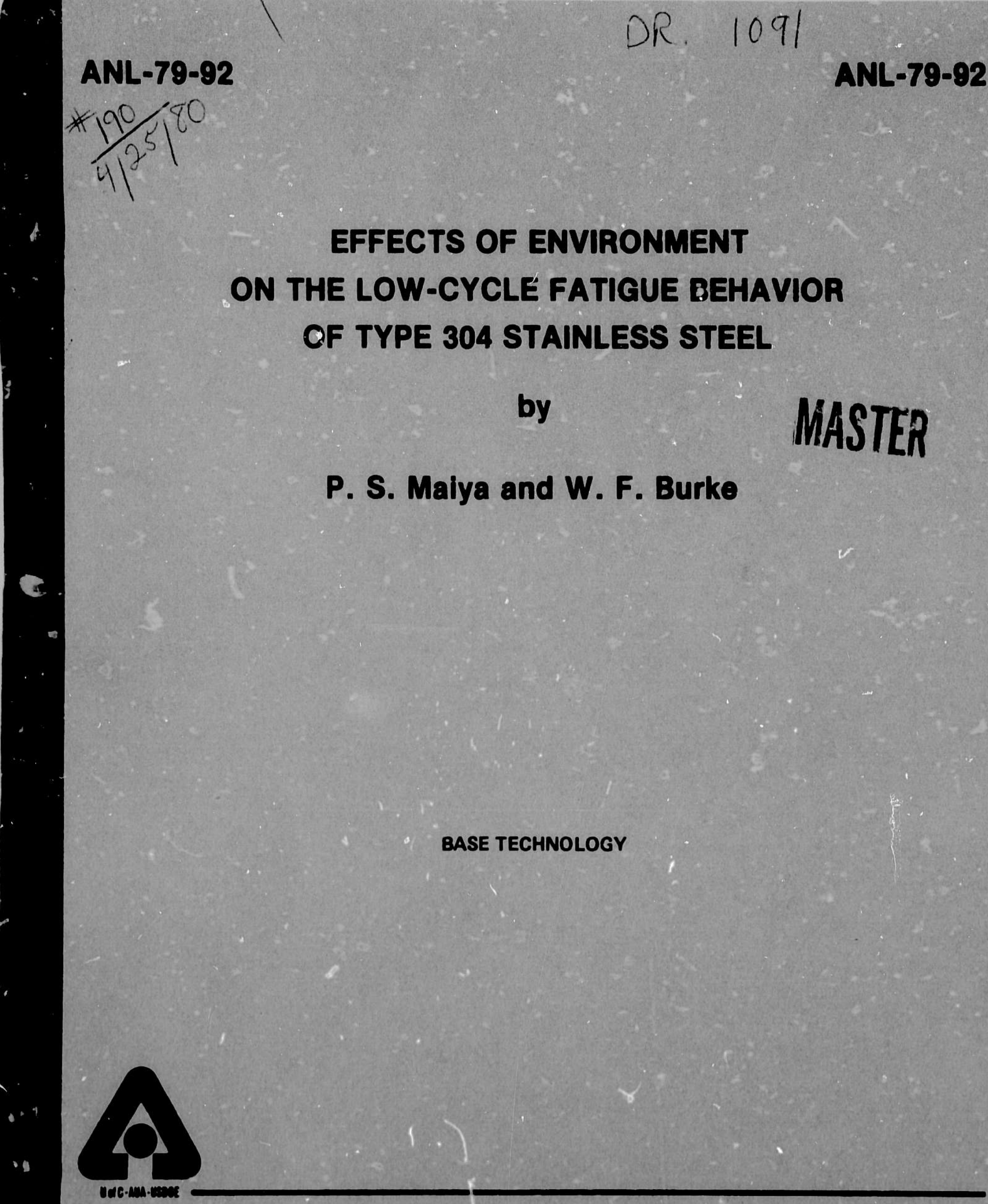

ARGONNE NATIONAL LABORATORY, ARGONNE, ILLINOIS

Propared for the U. S. DEPARTMENT OF ENERGY

under Contract W-31-109-Eng-38 
Distribution Category:

LMFBR-Structural Materials and Design Engineering (UC-79h)

ANL-79-92

ARGONNE NATIONAL LABORATORY

9700 South Cass Avenue

Argonne, Illinois 60439

\section{EFFECTS OF ENV IRONMENT \\ ON THE LOW-CYCLE FATIGUE BEHAVIOR \\ OF TYPE 304 STAINLESS STEEL}

by

P. S. Maiya and W. F. Burke

Materials Science Division

\section{December 1979}

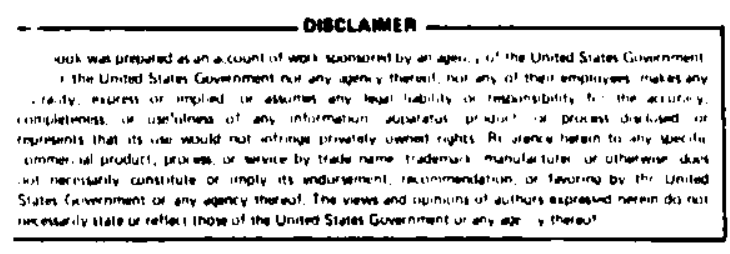


TABLE OF CONTENTS

Page

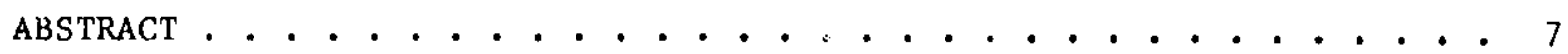
I. INTRODUCTION • • • • • • • • • • • • • • • • • • • . . . . . . 7 II. EXPERIMFNTAL DETAILS AND PROCEDURES • • • • • • • • • • • • • • • 8 III. RESULTS AND DISCUSSION • • • • • • • • • • • • • • • • • • • . 10 IV. SUMMARY AND CONCLUSIONS • • • • • • • • • • • • • • • • • • . . 16 ACKNOWLEDGMENTS • • • • • • • • • • • • • • • • • • • • . . . . 17 REFERENCES • • • • • • • • • • • • • • • • • • • • • • . . . . . 17 


\section{LIST OF FIGURES}

No. Title

Page

1. (a) High-vacuum Fatigue Testing System; (b) Specimen Assembly Inside the Vacuum Chamher . . . . . . . . . 9

2. A Schematic of the Apparatus for Conducting Low-cycle Fatigue Tests in Ultrahigh Vacuum . . . . . . . . . 10

3. Varlation of Fatigue Life with Total Strain Range . . . . 11

4. Variation of Fatigue Life with Plastic Strain Range . • . 11

5. Variation of Fatigue Life with Strain Rate . . . . . . . 13

6. Effect of Tensile Hold Time on Fatigue Life . . . . . . 14

7. Variation of Fatigue Life with Total Stra1n Range in Different Environments . . . . . . . . . . . . 16 


\section{LIST OF TABLES}

No.

I. Continuous-cycling Fat1gue Data for Type 304 Stainless Steel Tested in High Vacuum at $593^{\circ} \mathrm{C}$. . . . . . . . . 12

II. Hold-time Fatigue Data for Type 304 Stainless Stec1 Test in High Vacuum at $593^{\circ} \mathrm{C}$. . . . . . . . . . . 15

III. Low-cycle Fatigue Results for Type 304 Stainless Steel Tested in $\mathrm{H} 1 \mathrm{gh}$ Vacuum and $\mathrm{Alr}$ at $650^{\circ} \mathrm{C}$. . . . . . . . 15 



\title{
EFFECTS OF ENVIRONMENT ON TIIE LOW-CYCLE FATIGUE BEHAVIOR OF TYPE 304 STAINLESS STEEL
}

by

P. S. Maiya and W. F. Burke

\begin{abstract}
ABST'RACT
The low-cycle fatigue behavior of Type 304 stainless steel has been investigated at $593^{\circ} \mathrm{C}$ in a dynamic vacuum of better than $1.3 \times 10^{-6} \mathrm{~Pa}\left(10^{-8}\right.$ torr). The results concerning the effects of strain range, strain rate and tensile hold time on fatigue life are presented and compared with results of similar tests performed in air and sodium environmen:s. Under continuous symetrical cycling, fatigue life is significantly longer in vacuum than in air; in the low strain range regime, the effect of sodium on fatigue life appears to be similar to that of vacuum. Strain rate (or frequency) strongly influences fatigue life in both air and vacuum. In compressive hold-time tests, the effect of environment on life is similar to that in a continuous-cyziing test. However, tensile huld times are nearly as damaging in vacuum as in air. Thus, at least for austenitic stainless steels, the influence of the environment on fatigue life appcars to depend on the loading waveshape.
\end{abstract}

\section{INTRODUCTION}

The currently available design approaches to creep-fatigue life prediction for structural components are heavily based on creep-fatigue tests performed in an alr environment where creep-fatigue and oxidation/corrosion are known to interact. Therefore, the development of a true creep-fatigue model for a structural component in the absence of environmental interactions requires an understanding of the relative importance of corrosion and creepfatigue interaction under various loading conditions. Ore of the approaches for achieving such a goal is to conduct fatigue experiments in a well-defined high-vacuun environment (where the deieterious effects of environment are either minimized or completely eliminated) over a ralge of strains, strain rates and waveshapes including tensile and compressive hold times and other waveshapes that involve tensile or compressive imbalance of loading as in the case of "slow-fast" and "fast-slow" tests. Comparison of the high-vacuum test results with the existing data for fatigue in air will give some insight into the waveshape effects as well as the magnitude of oxidation or corrosion effects in degrading fatigue $11 \mathrm{fe}$ in an air environment. The influenne of high vacuum on low-cycle fatigue results has been emphasized by Coffin in his 
earlier work。1 The present report describes some preltminary investigations concerning the effects of ultrahigh vacuum on the low-cycle fatigue behavior of Type 304 stainless steel at $593^{\circ} \mathrm{C}$. It snould be noted that the majority of creep-fatigue tests for Type 304 stainless steel have been conducted in an air environment at $593^{\circ} \mathrm{C}$ and therefore the choice of this temperature for vacuum tests enables a meaningful comparison between the data generated in the two different environments.

\section{EXPERIMENTAL DETAILS AND PROCEDURES}

The starting material was Type 304 stainless steel (Heat 9T2796) in the form of hourglass-shape specimens $(6.35 \mathrm{~mm}$ minimum dia) prepared from a 15.5-mm-dia cold-drawn rod. The chemical composition has been reported elsewhere. ${ }^{2}$ In the as-fabricated condition, the specimens have a surface finish (rms value better than $0.3 \mu \mathrm{m}$ ) parallel to the longitudinal direction. The specimens were solution annealed in evacuated quartz tubes (backfilled with argon) for $30 \mathrm{~min}$ at $1092^{\circ} \mathrm{C}$ and aged for $1000 \mathrm{~h}$ at $593^{\circ} \mathrm{C}$. The aging treatment produces a relatively stable microstructure in the specimens and slightly increases the low-cycle fatigue strength. Because surface roughness can produce fatigue-life reduction or scatter in fatigue-1ife data, a consistent procedure ${ }^{2}$ was used to mechanically produce an $\in$ qually smooth surface finish on several specimens. For the mechanically polished sinooth specimens, the rms surface roughness as measured by interferometric techniques was better than $0.0075 \mu \mathrm{m}$.

The fatigue tests were performed in a Varian ultrahigh-vacuum system fitted into an MTS closed-loop electro-hydraulic materials iesting machine. The environmental system includes an ultrahigh-vacuum chamber, associated pumping systems, controls, and a quadrupole gas analyzer. Figure 1 shows the entire fatigue testing system and a view of the specimen assembly inside the high-vacuum chamber. A schematic of the entirc system is displayed in Fig. 2. The vacuum system employs copper gaskets of the Conflat and Wheeler types, oil-free roughing pumps (T), and a 200-l/s ion pump (R) backed by subsidiary titunfum sublimation ( $($ ) and cryogenic (P) pumps. The specimen was cycled under completely reversed push-pull conditions in an axial strain-control mode. The diametral strain extensometer (L) and load cell $(G)$ are located within the vacuum chamber. The procedure for conducting fatigue tests in vacium is essentially the same as that used in an air environment, although the vacuum procedure is more elaborate and time-consuming. As indicated in Fig. 2, the specimen installation is facilitated by a specially designed inside-out Conflat $f$ lange $(M)$ and a movable pumping system. The location of the load cell (G) is such that it is unaffected by the friction of the die set (D), the effect of vacuum on the bellows, and the spring constant of the bellows $(H)$. Nfter loading the specimen in the chamber, the systcm is closed and evacuated to a pressure of $6.7-9.3 \times 10^{-6}$ $\mathrm{Pa}\left(5-7 \times 10^{-8}\right.$ torr). At this point, the system is baked for $8 \mathrm{~h}$ at $120-$ $150^{\circ} \mathrm{C}$; this reduces the pressure to $6.7 \times 10^{-7} \mathrm{~Pa}\left(\sim 5 \times 10^{-9}\right.$ torr). At these low pressures, the predominant background 1mpurity species as measured by thi gai inalyzer is hydrogen. Prior to fatigue testing, the specimen 1 s brought to the approprfate temperature by induction heating; the temperature 


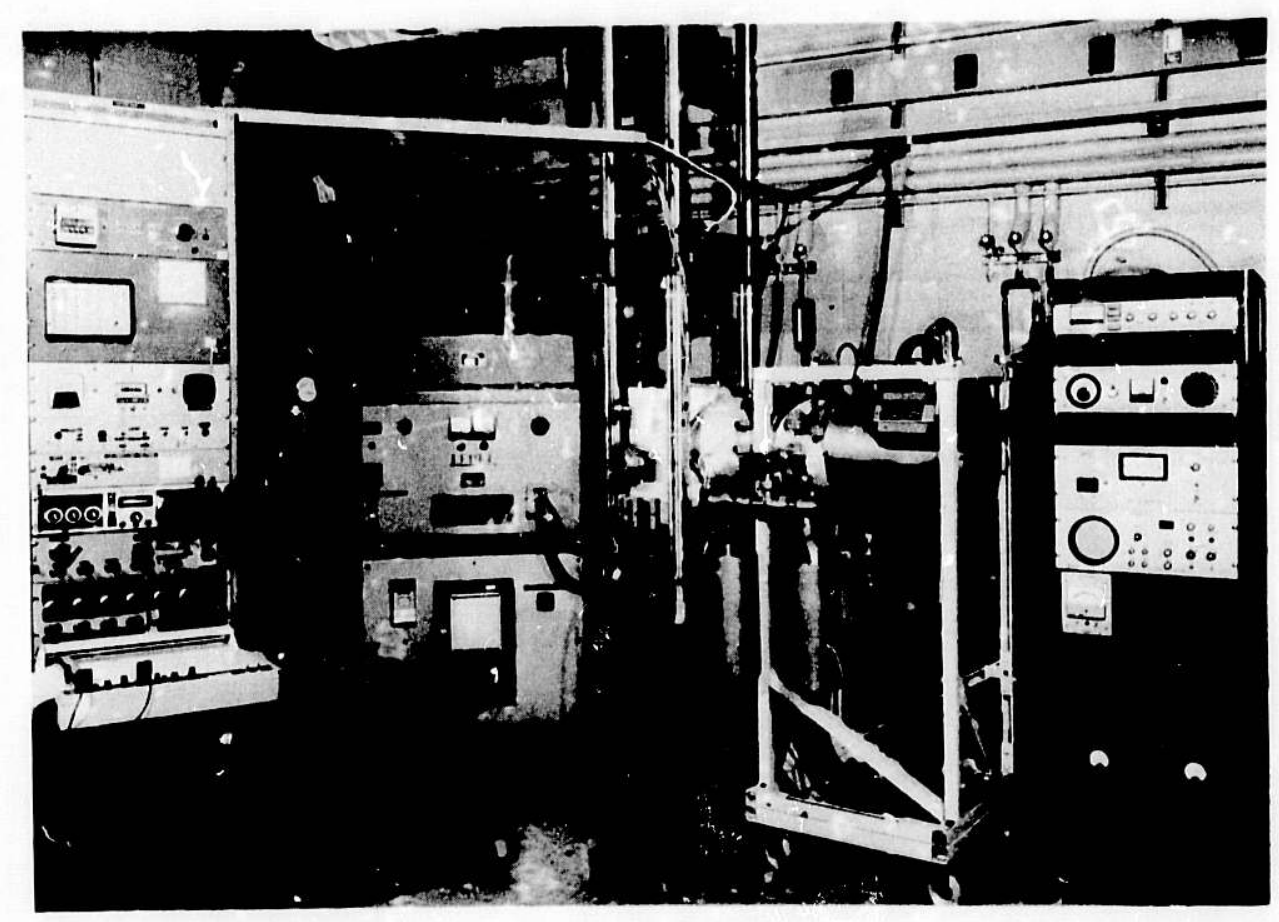

(a)

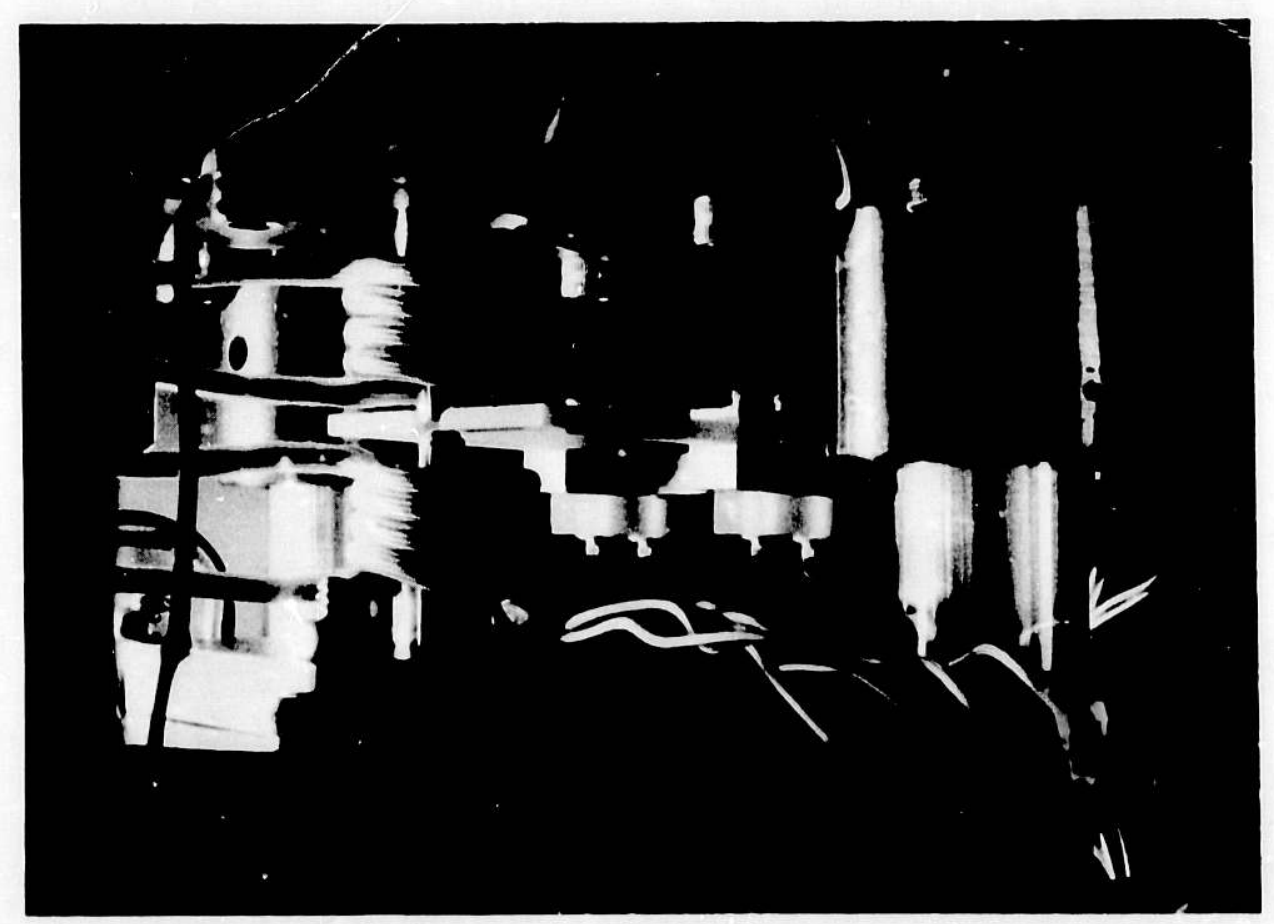

(b)

Fig. 1. (a) High-vacuum Fatigue Testing System; (b) Specimen Assembly Inside the Vacuum Chamber. ANL Neg. Nos. 134-79-238 and 134-79-236. 


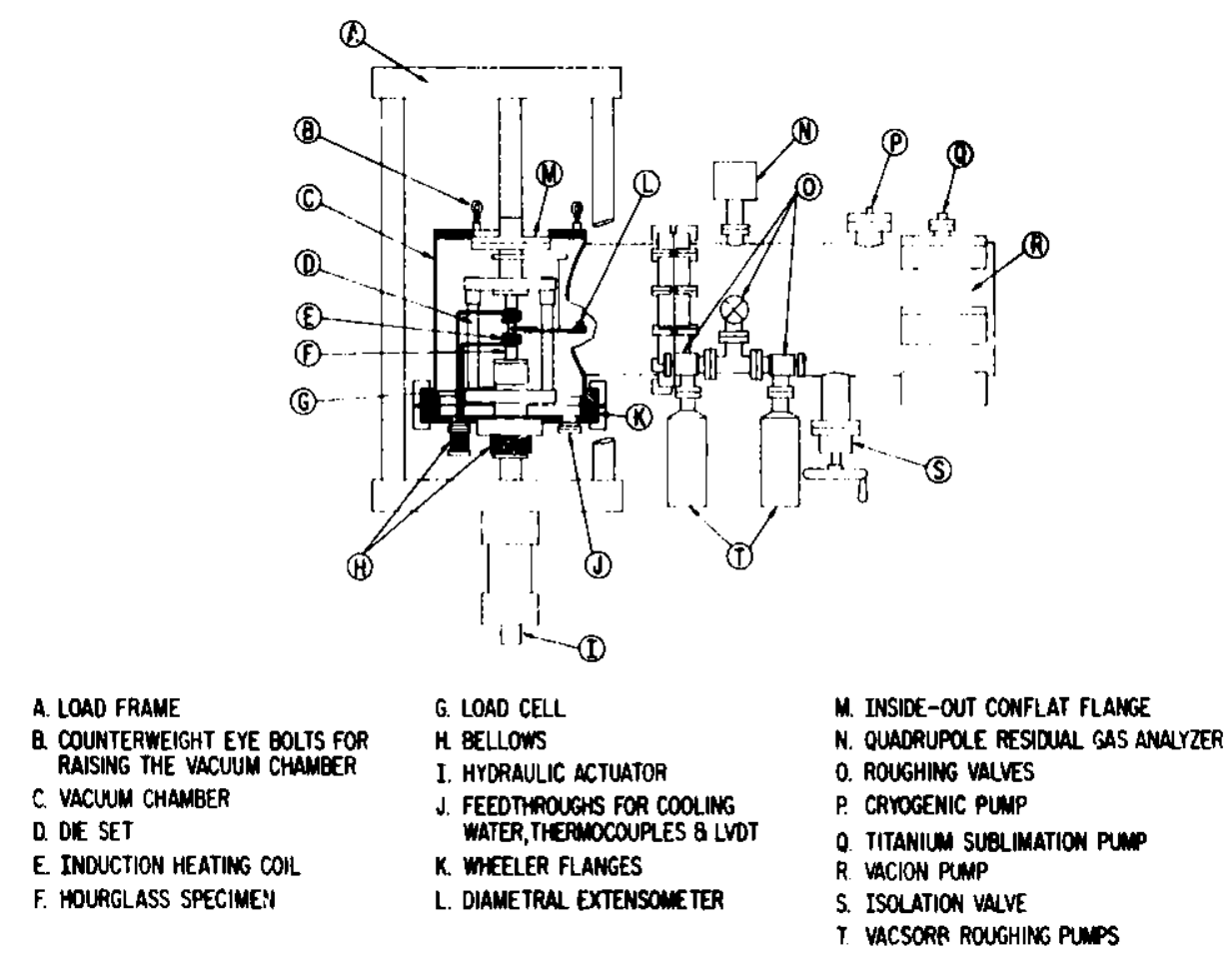

Fig. 2. A Schematic of the Apparatus for Conducting Low-cycle Fatigue Tests in U1trahigh Vacuum. ANL Neg. No. 306-79-139.

balance is accomplished by means of an adjustable RF bellows feedthrough (H). All the test results described here were obtained under identical conditions of a dynamic vacuum better than $1.3 \times 10^{-6} \mathrm{~Pa}\left(1 \times 10^{-8}\right.$ torr). This report presents the low-cycle fatigue results for Type 304 stainless steel as influenced by total strain ranges from 0.5 to $2.0 \%$, strain rates between $4 \times 10^{-3}$ and $4 \times 10^{-5} \mathrm{~s}^{-1}$, and tensile hold time of 1 to $60 \mathrm{~min}$ imposed in each cycle.

\section{RESULTS /ND DISCUSSION}

\section{A. Comparison Between the Results Obtained in Vacuum and Air}

The variation of fatigue life with total and plastic strain range for the fatique data obtained with continuous symmetrical cycling in high vacuum is shown in Figs. 3 and 4 . The total $\left(\Delta \varepsilon_{t}\right)$ and plastic $\left(\Delta \varepsilon_{p}\right)$ strain ranges, saturation stress range $(\Delta \sigma)$ obtained at approximately half the fatigue $11 \mathrm{fe}$, number of cycles to fallure $\left(N_{f}\right)$ under continuous cycling at different strain rates $\left(\dot{\varepsilon}_{t}\right)$, and the fatigue-11fe enhancement factor in vacuum [ $\mathrm{N}_{\mathrm{f}}$ (vacuum; $/ \mathrm{N}_{\mathrm{f}}(\mathrm{air})$ ] are 11sted in Table $\mathrm{I}$. A comparison with similar results obtained in an alr environment ${ }^{3-5}$ suggests that the 1 ife in vacuum is longer by a factor of $\sim 3-5$ at total strin ranges between 0.5 and $2.0 \%$ and $\dot{\varepsilon}_{t}=4 \times 10^{-3} \mathrm{~s}^{-1}$. In both cases, the fallure mode occurs by crack initiation at the surface and its subsequent propagation to fallure. Where- 


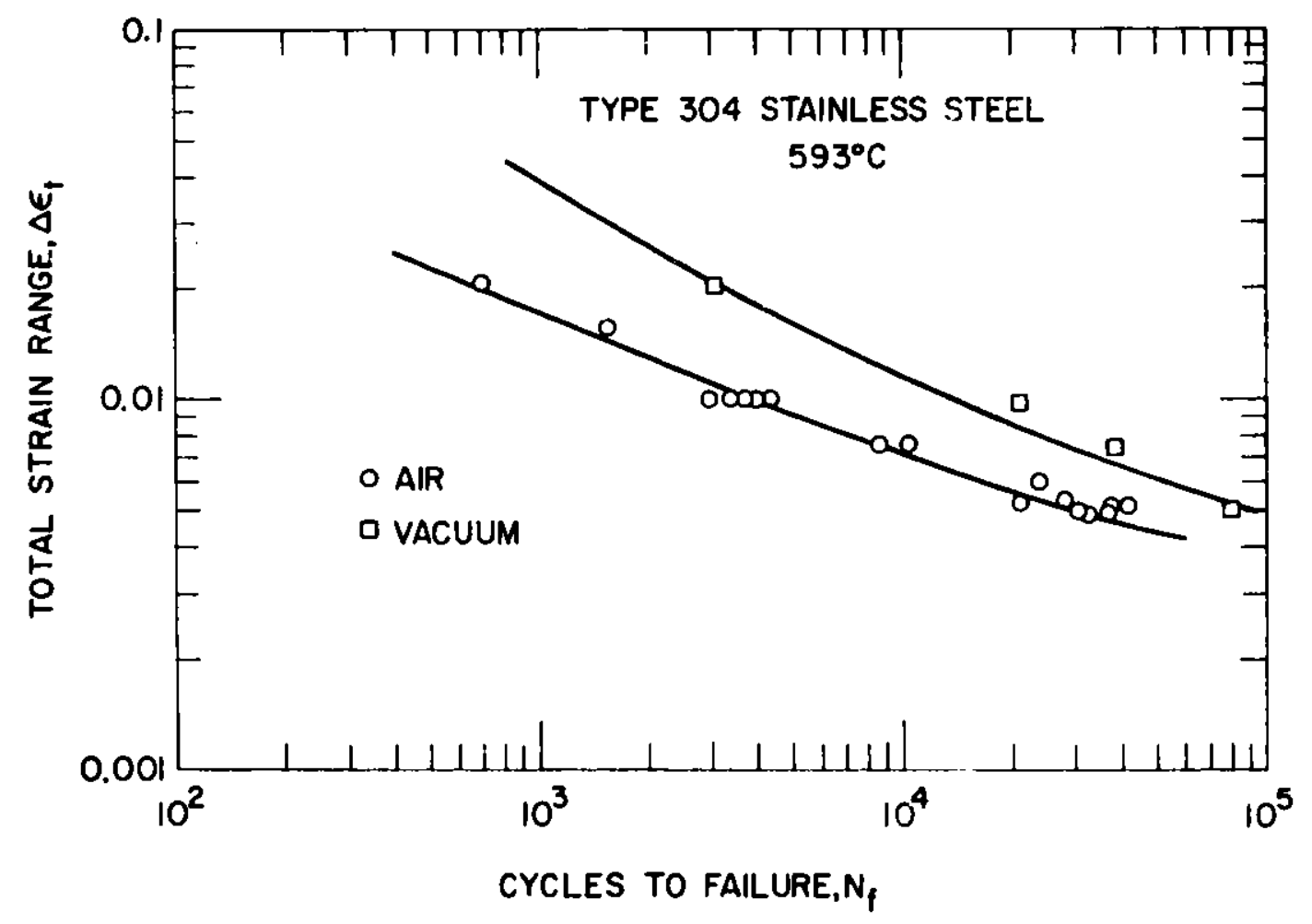

Fig. 3. Variation of Fatigue Life with Total Strain Range. Strain Rate $=4 \times 10^{-3} \mathrm{~s}^{-1}$. ANL Neg. No. 306-78-530.

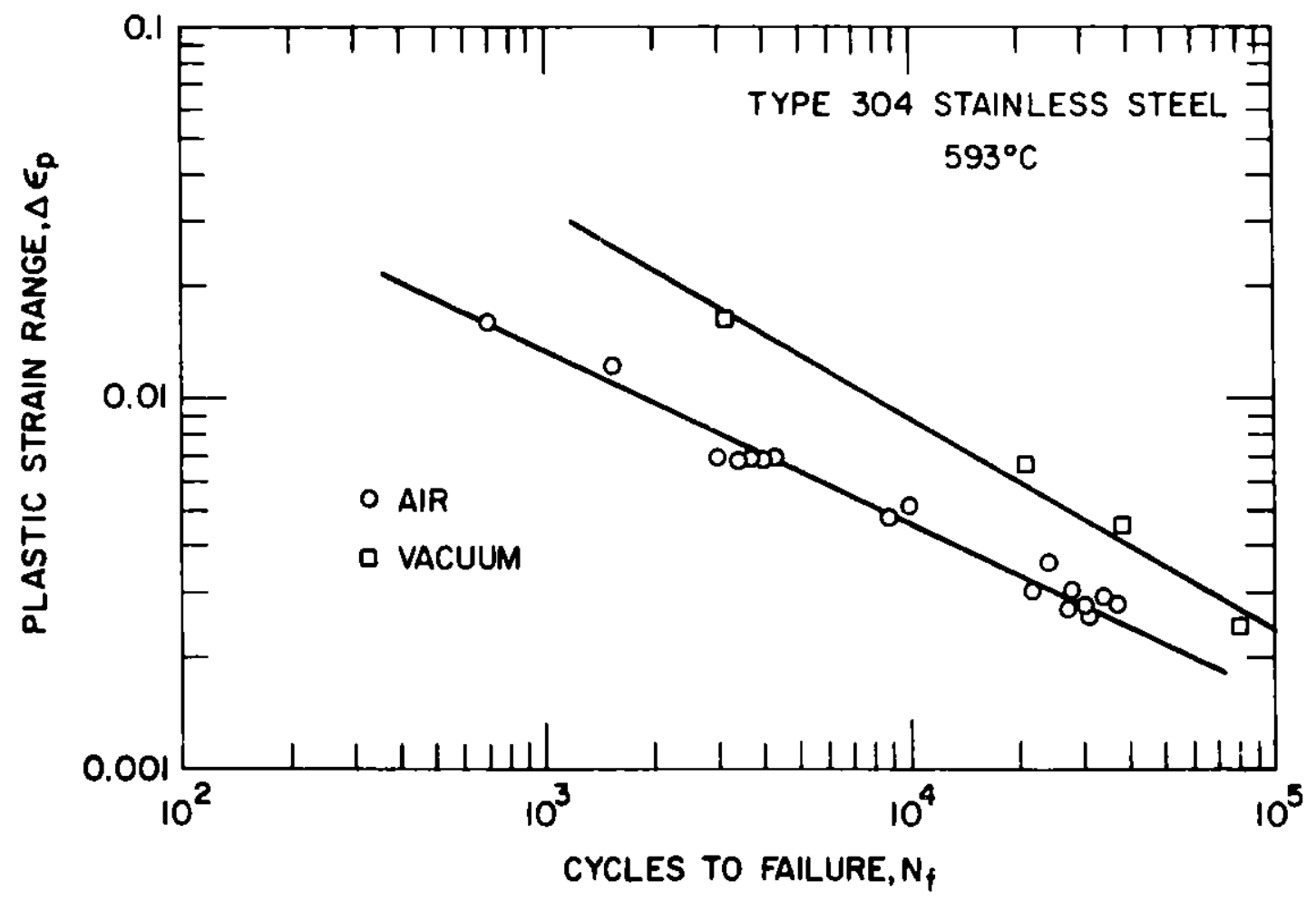

Fig. 4. Variation of Fatjgue Life with Plastic Strain Range. Strain Rate $=4 \times 10^{-3} \mathbf{s}^{-1}$. ANL Neg. No. 306-78-529. 
Table I. Continuous-cycling Fatigue Data for Type 304 Stainless Stee1 Tested in High Vacuum at $593^{\circ} \mathrm{C}$

\begin{tabular}{ccccccc}
$\begin{array}{l}\text { Test } \\
\text { No. }\end{array}$ & $\begin{array}{c}\Delta \varepsilon_{\mathrm{t}}, \\
\%\end{array}$ & $\begin{array}{c}\Delta \varepsilon_{\mathrm{p}}, \\
\%\end{array}$ & $\begin{array}{c}\dot{\varepsilon}_{\mathrm{t}}, \\
\mathrm{s}^{-1}\end{array}$ & $\begin{array}{l}\Delta \sigma, \\
\mathrm{MPa}\end{array}$ & $\mathrm{N}_{\mathrm{f}}$ & $\frac{\mathrm{N}_{\mathrm{f}} \text { (vacuum) }}{\mathrm{N}_{\mathrm{f}} \text { (air) }}$ \\
\hline 940 & 0.50 & 0.24 & $4 \times 10^{-3}$ & 383.6 & 80640 & 2.4 \\
965 & 0.75 & 0.45 & $4 \times 10^{-3}$ & 457.1 & 38670 & 4.4 \\
931 & 1.00 & 0.66 & $4 \times 10^{-3}$ & 502.0 & 21218 & 5.3 \\
949 & 2.01 & 1.59 & $4 \times 10^{-3}$ & 639.0 & 3115 & 4.5 \\
935 & 0.99 & 0.65 & $4 \times 10^{-4}$ & 512.6 & 11169 & 4.3 \\
1023 & 0.99 & 0.69 & $4 \times 10^{-5}$ & 454.4 & 6509 & 5.9 \\
\hline
\end{tabular}

as well-defined fatigue striations are present on the fracture surfaces of specimens tested to failure in air, fatigue striations are not observed on the vacuum-tested specimens. These observations are consistent vith a suggestion made by Pelloux ${ }^{6}$ concerning the formation of fatigue striations. In an environment such as air, newly formed slip steps are easily oxidized. In vacuum, this does not occur and the slip should more easily reverse. This may account for the absence of striations on the fracture surfaces of specimens tested in vacuum.

The effect of strain rate on fatigue life of Type 304 stainless steel under continuous symmetrical cycling in vacuum compared with that in air at $593^{\circ} \mathrm{C}$ and a total strain range of $1 \%$ is shown in Fig. 5. The data generated in an air environment are selected from Refs. 3-5. It is clear from Fig. 5 that the fatigue life in vacuum is longer than that in air by a factor of $\sim_{4-6}$ and fatigue 1 ife in both environments decreases with a decrease in strain rate. Furthermore, the fatigue-life reduction factor, defined as $N_{f}$ (at any strain rate)/ $N_{f}$ (at the fastest strain rate) where $N_{f}$ is the number of cycles to failure, is approximately the same for both environments. For example, in both air and vacuum environments, the fatigue life can decrease by approximately a factor of 3-4 with a decrease in strait rate from $4 \times 10^{-3}$ to $4 \times 10^{-5} \mathrm{~s}^{-1}$. These results demonstrate that even in vacuum there exists a strong strain-rate effect on life.

Coffin ${ }^{1}$ has also investigated the effect of high vacuum $\left(1.3 \times 10^{-6}\right.$ $\mathrm{Pa} ; 10^{-8}$ torr) on the low-cycle fatigue 1 ife of a few materials which included Nickel A, Tyne 304 stainless steel, and alloys A286, C1010 and $7075 \mathrm{~T} 6$. For the materials and experimental conditions used, he concluded that the effects of frequency on life are not important in high vacuum, contrary to the findings of the present study. His conclusion with respect to Type 304 stainless steel. Is based on two tests in vacuum at $816^{\circ} \mathrm{C}$, one conducted at a frequency of $1 \mathrm{cpm}$ and a plastic strain range of 0.01 and another at $5 \mathrm{cpm}$ and a plastic strain range of 0.005 , which are not sufficient to arrive at a conclusion concerning frequency effects. 


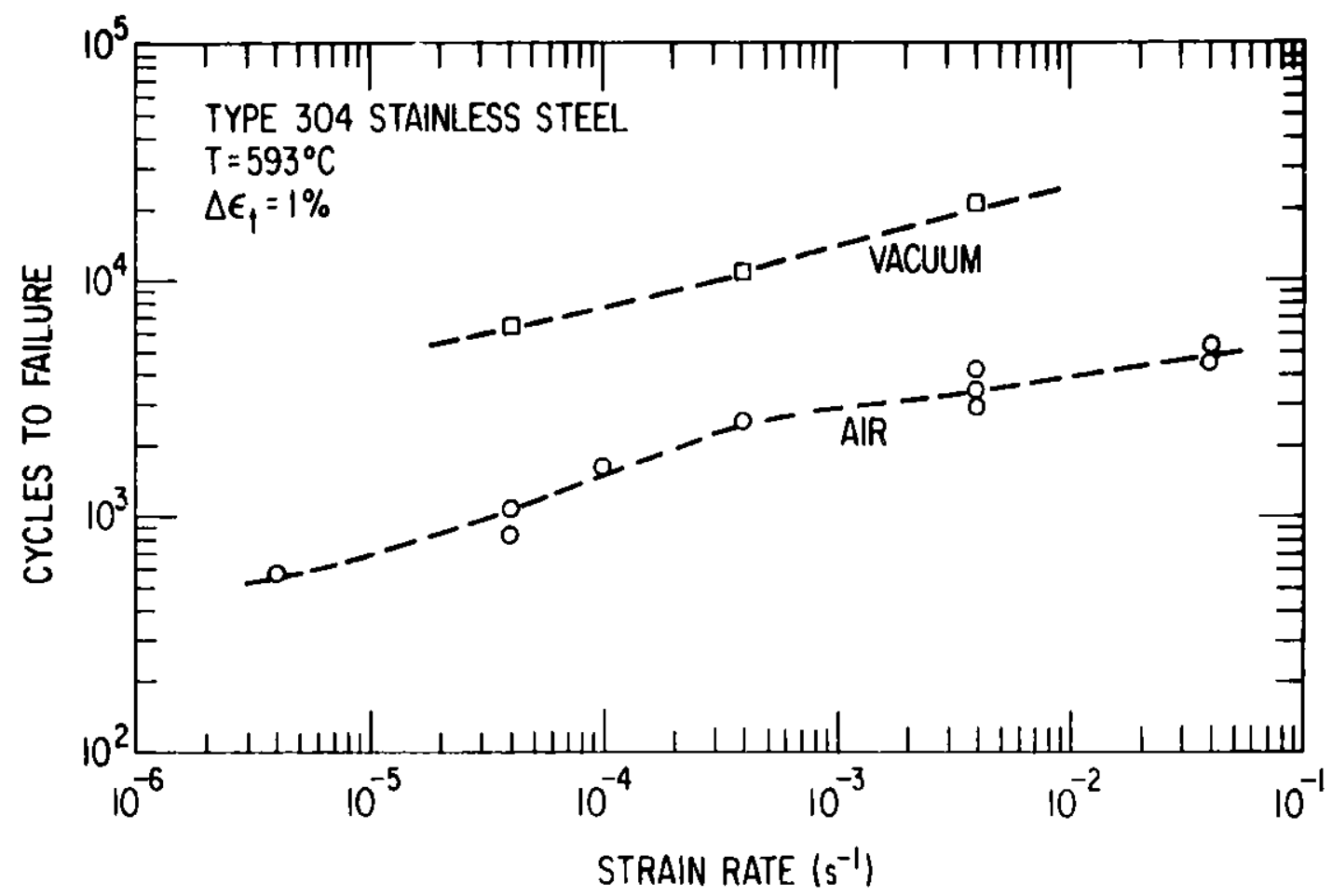

Fig. 5. Variation of Fatigue Life with Strain Rate. ANL Neg. No. 306-79-137.

Under conditions of continuous symmetrical cycling, failure occurs by crack initiation at the surface and its propagation to failure. In an air environment, the fatigue behavior for this waveshape is expected to be influenced by oxidation. In high vacuum, the reduction in life with a decrease in strain rate is primarily attributed to creep effects. To illustrate the effect of oxidation on fatigue damage, we assume that the total damage in air is a sum of damage due to creep and damage associated with oxidation (the interactive effects of oxidation and creep-fatigue are ignored); i.e.,

$$
\left(\frac{1}{N_{f}}\right)_{\text {air }}=\left(\frac{1}{N_{f}}\right)_{\text {vacuum }}+\left(\frac{1}{N_{f}}\right)_{\text {oxidation }}
$$

Using Eq. (1), one finds that with a decrease in strain rate from $4 \times 10^{-3}$ to $4 \times 10^{-5} \mathrm{~s}^{-1}$, the damage per cycle due to oxidation increases from $2.1 \times 10^{-4}$ to $7.5 \times 10^{-4}$. This simple illustration shows that the longer the time of the fatigue test, the greater is the effect of oxidation.

Examination of the data in air and vacuum environments at different strain ranges shows that the effect of oxidation may be enhanced by an increase in the cyclic strain range and time of cycling. For example, the fatigue 1ifetime for test no. 940 at $\Delta \varepsilon_{t}=0.5 \%$ is longer than that for tests conducted at higher strain ranges, yet the ratio $\mathrm{N}_{\mathrm{f}}$ (vacuum) $/ \mathrm{N}_{\mathrm{f}}$ (air) is lower for this test. This may be explained from the observation that the dependence of lifetime on strain range is stronger in air than in vacuum; e.g., fatigue life in air decreases by a factor of 8 with an increase in 
cyclic straln range from 0.5 to $1 \%$, whereas under similar conditions in vacuum the life decreases only by a factor of 4 . These results suggest that both time and strain range of cycling play a role in oxidation. This conclusion is substantiated by the results of a much earlier study by Cof $\mathrm{fin}^{7}$ on the low-cycle fatigue behavior of austenitic alloys. He found that significant cyclic oxidation of alloys occurs at elevated temperatures. In fact, he has suggested on the basis of experimental observations that the oxidarion is more strongly influenced by cyclic plastic strain than by time at a fixed temperature.

In tensile hold-time tests, failure occurs predominantly by the initiation, growth and subsequent linkage of grain-boundary cavities. In contrast to continuous cycling, the fatigue behavior for this waveshape is not expected to be significantly affected by environment, as can be seen in Fig. 6 and Table II. Figure 6 shows the variation of fatigue life with tensile hold time at $593^{\circ} \mathrm{C}$ and a total strain range of $1 \%$ in the two environments. It is clear that with zero tensile hold time (i.e., continucus cycling), the fatigue 1 ife in vacuum is significantly longer than that in air (as discussed earlier), but with the imposition of tensile hold time the vacuum data approach those for air. In contrast, with compressive hold time (which 1s less damaging than tensile hold time), the life in vacuum is longer than that in air by a factor of 4 (Tabie II).

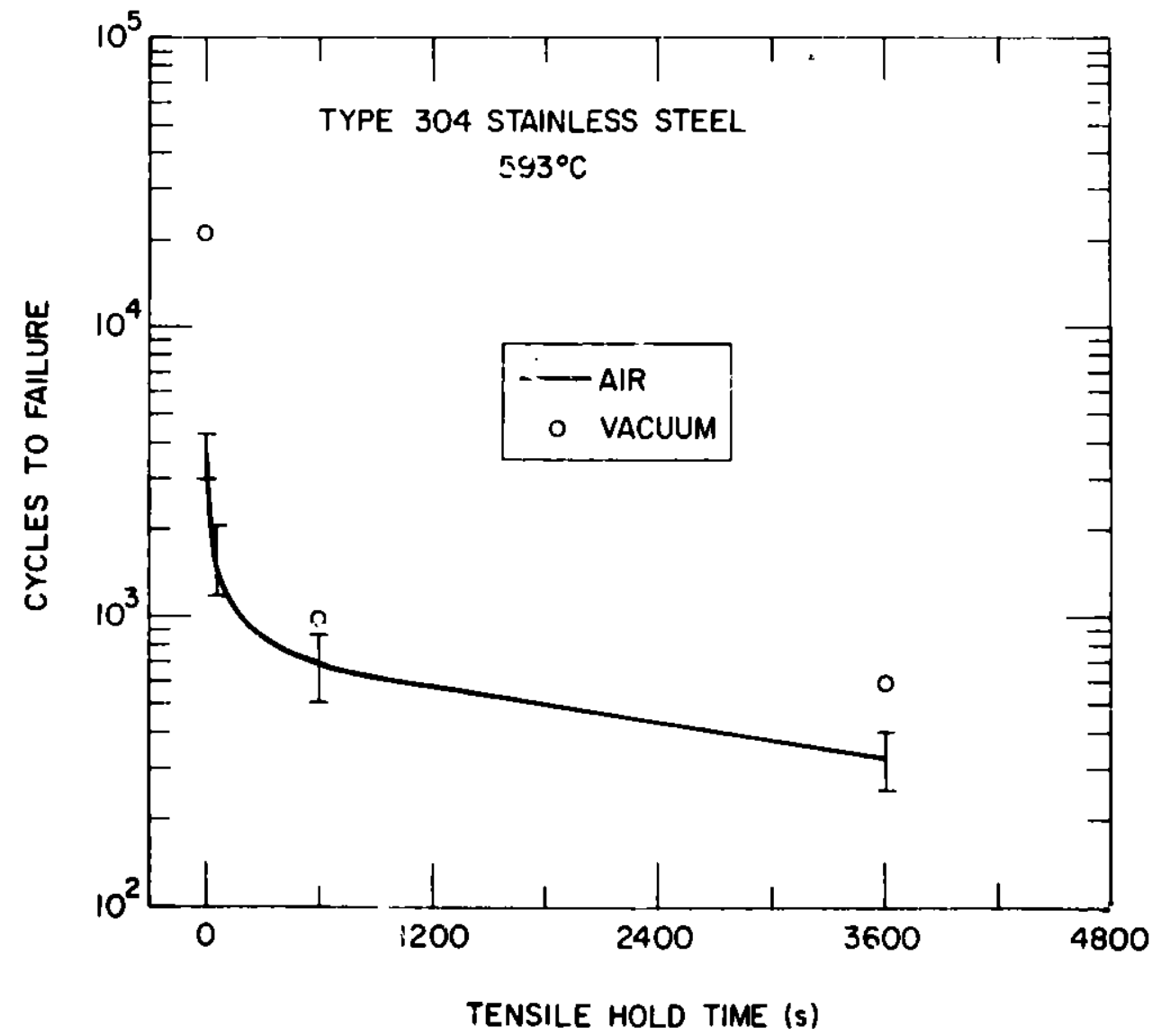

F1g. 6. Effect of Tensile Hold Time on Fatigue Life. Tctal Strain Range $=1 \%$. ANL Neg. No. 306-78-532. 
Table II. Hold-time Fatigue Data for Type 304 Stainless Steel Tested in High Vacuum at $593^{\circ} \mathrm{C}$

\begin{tabular}{|c|c|c|c|c|c|c|c|}
\hline $\begin{array}{l}\text { Test } \\
\text { No. }\end{array}$ & $\underset{\%}{\Delta \varepsilon_{t}}$, & $\underset{\%}{\Delta \varepsilon_{p}}$, & $\begin{array}{l}\dot{E}_{t} \\
s^{-1}\end{array}$ & $\underset{\mathrm{MPa}}{\Delta \sigma(\max ),}$ & $\begin{array}{l}\text { Hold } \\
\text { mins }\end{array}$ & $\mathrm{N}_{\mathrm{f}}$ & $\frac{\mathrm{N}_{\mathrm{f}} \text { (vacuum) }}{\mathrm{N}_{\mathrm{f}}(\mathrm{a} I \mathrm{r})}$ \\
\hline 996 & 1.00 & 0.74 & $4 \times 10^{-3}$ & 428.4 & $10 \mathrm{~T}$ & 909 & 1.3 \\
\hline 976 & 0.98 & 0.71 & $4 \times 10^{-3}$ & 407.6 & $60 \mathrm{~T}$ & 590 & $1.9^{\mathrm{b}}$ \\
\hline 1051 & 0.99 & 0.70 & $4 \times 10^{-3}$ & 473.0 & $2 \mathrm{C}$ & 12425 & 4.2 \\
\hline
\end{tabular}

A few low-cycle fatigue tests have been performed on Type 304 stainless steel at $650^{\circ} \mathrm{C}$ in both vacuum and air. ${ }^{8}$ The results pertinent to the present study are shown in Table III. In the slow-fast test, the tensile strain rate is slower than the compressive strain rate. Similar tests have also been performed in an a1r environment at Argonne National Laboratory. 9 The drastic reduction in life associated with slow-fast loading is due to the initiation and growth of grain-boundary cavities and their interaction with a crack. 9 The slow-fast test results given in Table III also show that the lives in vacuum and air are approximately equal under creep-fatiguc loading conditions where grain-boundary cavity damage predominates, as in the case of tensile hold-time tests; this is consistent with the present results.

Table III. Low-cycle Fatigue Results ${ }^{a}$ for Type 304 Stainless Steel Tested in High Vacuum and Air at $650^{\circ} \mathrm{C}$

\begin{tabular}{|c|c|c|c|c|c|c|}
\hline Environment & $\begin{array}{l}\text { Type } \\
\text { of } \\
\text { Test }\end{array}$ & $\underset{\%}{\Delta \varepsilon_{p}}$ & $\begin{array}{c}\text { Frequency, } \\
\text { cpm }\end{array}$ & $\begin{array}{c}\text { Tension-going } \\
\text { Time, } \\
\text { min }\end{array}$ & $\begin{array}{c}\text { Compression-going } \\
\text { Time, } \\
\text { min }\end{array}$ & $\mathrm{N}_{\mathrm{f}}$ \\
\hline Air & Equa1 & 2.0 & 0.1 & 5.0 & 5.0 & 215 \\
\hline Air & $\begin{array}{l}\text { Slow- } \\
\text { Fast }\end{array}$ & 2.0 & 0.1 & 9.9 & 0.1 & 106 \\
\hline Vacuum & Equal & 2.0 & 0.05 & 10.0 & 10 & 1407 \\
\hline Vacuim & $\begin{array}{l}\text { Slow- } \\
\text { Fast }\end{array}$ & 2.0 & 0.1 & 1.0 .0 & 0.1 & 148 \\
\hline
\end{tabular}

\footnotetext{
${ }^{\mathrm{a}}$ From Ref, 8 .
} 
B. Comparison Between the Results Obtained in Vacuum and Sodium

A comparison of the continuous-cycling fatigue results obtained in high-vacuum and sodium environments for heat-treated material is shown in Fig. 7. The sodium data are taken from Refs, 10 and 11 . It should be mentioned that under the experimental conditions used in the sodium runs (equivalent to vacuum better than $1.3 \times 10^{-18} \mathrm{~Pa}$ or $10^{-20}$ torr), one would expect the data obtalned to be close to thos for righ vacuum. Within the framework of the limited data base, this appears to be true. The slightly lower life generally observed in sodium compared to that in vacuum may be attributed to the specimen shape: The data obtained in sodium are for tests conducted on straight-gauge specimens, whereas the vacuum data are for hourglass-shape specimens. For a more meaningful comparison of the fatigue behavior, it would be desirable to have more data in both environments (sodium and vacuum); this wouid help in quantitating the effects of strain, strain rate, temperature, wave shape and environmental effects of 1 ife and would provide a better understanding of creep-fatigue damage.

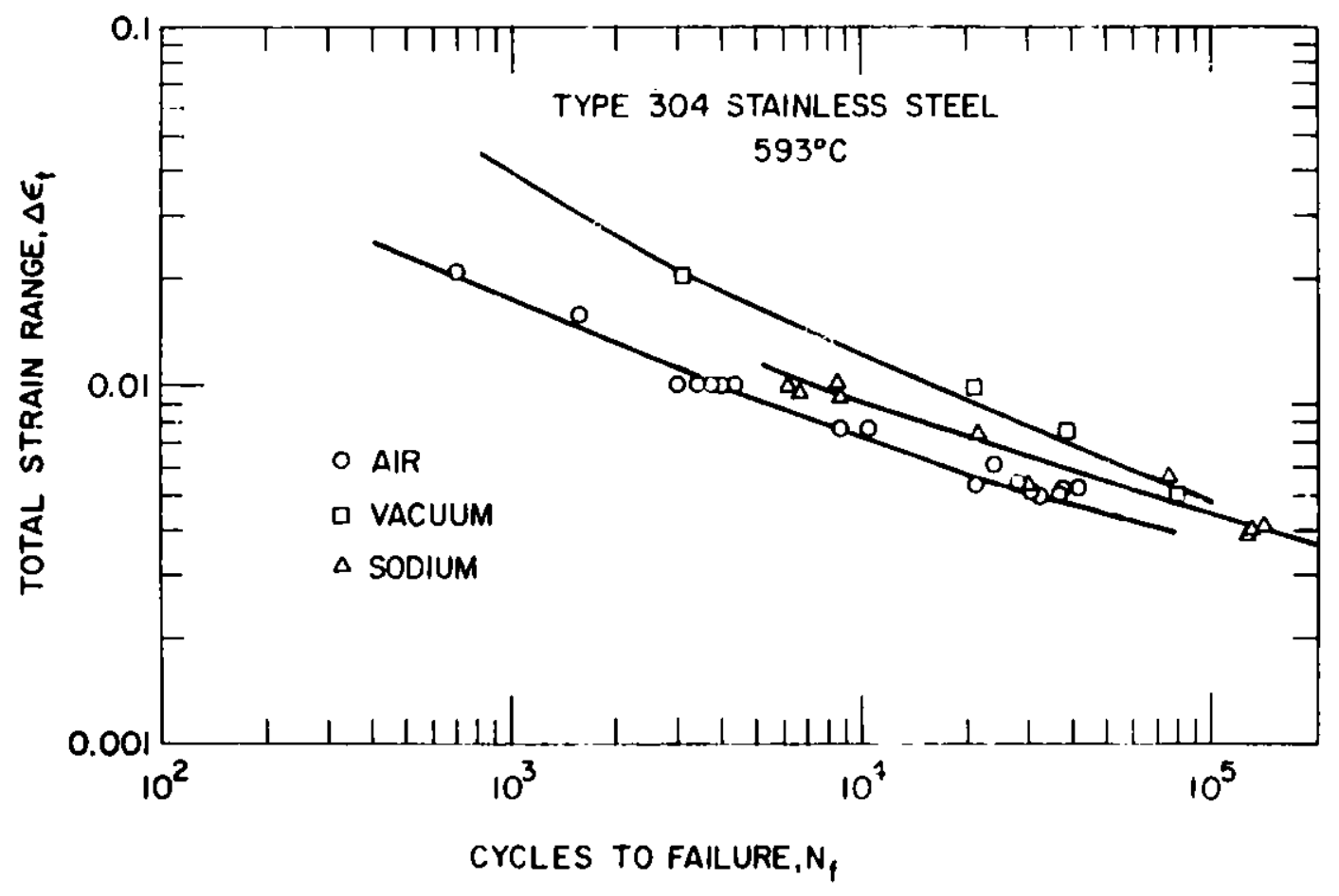

Fig. 7. Varlation of Fatigue life with Total strain Range in Different Environments. Strain Rate $=4 \times 10^{-3} \mathrm{~s}^{-1}$. ANI Neg. No. $306-78-533$.

IV. SUMMARY AND CONCLUSIONS

The low-cycle fatigue results obtained for Type 304 stainless steel at $593^{\circ} \mathrm{C}$ in high vacuum show that under continuous symetrical cycling, 
fatigue life is longer in vacuum than in air by a factor of 3-5 at total strain ranges between 0.5 and $2.0 \%$. The extent of life reduction resulting from a decrease in strain rate is anproximately the same in vacuum and air. Sodium and vacuum environments appear to produce identical effects on fatigue 1ife. As in continuous-cycling tests, the fatigue life of a specimen in a compressive hold-tilne test is observed to be longer in vacuum than in air by a factor of 4. Under tensile hold-time conditions, the lives in vacuum and air are approximately the same. These results show that the effects of an oxidizing environment on low-cycle fatigue life at elevated temperature are significant only for those cyclic loading conditions which promote failure by crack initiation at the surface and subsequent propagation to failure; the effects are not significant when the testing conditions are favorable for. failure by initiation and growth of grain-boundary cavities. The results further demonstrate the potential of using a vacuum environment to investigate creep-fatigue interaction in a structural component in the absence of environmental interaction:

\section{ACKNUWLEUCMENTS}

We would like to thank R. W. Weeks and W. J. Shack for their support and encouragement and D. F. Busch for his help in the early stages of the design of the vacuum chamber.

\section{REFERENCES}

1. L. F. Coffin, Jr., "The Effect of High Vacuum on the Low-cycle Fatigue Law," Met. Trans. 3, 1777-1788 (1972).

2. P. S. Maiya and D. E. Busch "Effect of Surface Roughness on Low-cycle Fatigue Behavior of Type 304 Stainless Stee1," Met. Trans. 6A, 1761-1766 (1975).

3. D. R. Diercks and D. T. Raske, "Elevated Temperature, Strain-controlled Fatigue Data on Type 304 Stainless Steel: A Compilation, Multiple Linear Regression Mode], and Statistical Analysis," Argonne National Laboratory Report ANL-76-95 (December 1976).

4. P. S. Malya and S. Mafumdar, "Elevated Temperature Lcw-cycle Fatigue Behavior of Different Heats of Type 304 Stainless Steel," Met. Trans. 8A, 1651-1660 (1977).

5. P. S. Maiya, "Considerations of Crack Inftiation and Crack Propagation in Low-cycle Fatigue," Scripta Met. 9, 1141-1146 (1975).

6. R. M. N. Pelloux, "Mechanism of Formation of Ductile Fatigue Striations," Trans. ASM 62, 281-285 (1969). 
7. L. F. Coffin, Jr., "Cyclic-Strain-Induced Oxidation of High-Temperature Alloys," Trans. ASM 56, 339-344 (1963).

8. L. F. Coffin, Jr., "Observations and Correlations Emphasizing Frequency and Environmental Effects," Tine-Dependent Fatigue or Structural Alloys, Oak Ridge National Laboratory Report ORNL-5073 (June 1977).

9. S. Majumdar and P. S. Maiya, "A Mechanistic Model for Time-Dependent Fatigue," to be published in Trans. ASME.

10. K. Natesan, O. K. Chopra, G. J. Zeman, D. L. Smith and T. F. Kassner, in Proc. IAEA/IWGFR Specialists' Meeting on Properties of Primary Circuit Structural Materlals Including Environmental Effects, CONF-771052, p. 16 (1977).

11. Oak Ridge National Labcratory, Merhanical Properties Test Data for Structural Materials Semiannual Progress Report for Period Ending August 15, 1979, in press. 